\title{
Soil compaction by the tractor in spring and its effect on soil porosity
}

\author{
ERKKI AURA
}

Agricultural Research Centre, Department of Agricultural Chemistry and Physics, 31600 Jokioinen

\footnotetext{
Abstract. The effect on soil porosity of tractor compaction of soil in the spring was studied by taking cylindrical core soil samples. The profile samples showed that the tractor most seriously compacts the soil below the harrowed layer at the depth of $10-25 \mathrm{~cm}$. Soil was compacted most severely when tillage and drilling were performed under wet conditions about one week before normal sowing time. The subsoil at the depth of $35-40 \mathrm{~cm}$ was compacted only under very wet conditions. The grain yield of wheat was significantly reduced when the volume of large pores was reduced to about $10 \%$ or less. Porosity measurements showed that the severely compacted soil almost completely recovered from one spring to the next.

Theoretical calculations suggested that compaction by normal traffic does not cause a shortage of oxygen at least in the inter-crumb pores of soil if the soil surface structure is not dispersed and encrusted. The decrease in crop growth by compaction is primarily due to mechanical impedance, which slows down development of the root system.
}

\section{Introduction}

The compacting of soil by traffic on the field in spring increases the bulk density and reduces both the pore space and the air content of soil. Primarily, soil compaction causes a reduction in the volume of large pores $(\varnothing>30 \mu \mathrm{m})$. The volume of mediumsize and small pores is much less influenced by such traffic (e.g. ERIKSSON et al. 1974). The greater mechanical impedance to plant roots and lower hydraulic conductivity of saturated soil in compacted fields are due to the reduction of large pores. The compacting of soil also slows down the diffusion of gases. The aim of this study was to clarify the effects of tractor traffic in the spring on porosity conditions in soil. The study also includes observations on how soon soil severely compacted during three successive years can recover if only moderately compacted in the fourth spring. The effect of traffic on the mechanical impedance and aeration of soil was also examined. 


\section{Experimental}

A detailed description of the field experiments was presented earlier by ELONEN $(1979,1980)$. The factors affecting the compacting of soil in spring were:

1. Tillage and sowing time

$\mathrm{T} 1=$ Tillage and sowing about a week before the normal time and under wet conditions

$\mathrm{T} 2$ = Tillage and sowing at the normal time, when soil moisture conditions were favourable

\section{Compacting of soil}

$\mathrm{CO}=$ No traffic by the tractor, only spring tillage and sowing

$\mathrm{C} 1$ = Twice with a double-wheeled tractor over the whole surface area of soil at tillage and sowing

$\mathrm{C} 2$ = Normal compaction. Once with a single-wheeled tractor over the whole surface area at tillage, plus sowing

C3 3 Severe compaction. Before tillage twice with a single-wheeled tractor + normal compaction.

The fields were harrowed to the depth of about $8 \mathrm{~cm}$. Spring wheat or barley (Laukaa field) was sown to a depth of about $5 \mathrm{~cm}$.

The characteristics of the experimental soils are shown in Table 1. Fields were treated in the same way during three successive years 1975-77. In 1978, the recovery of compacted soil was studied as follows: previous T1-plots were harrowed and drilled at the normal time using a double-wheeled tractor (C1-treatment), while previous T2-plots were compacted as in earlier years but the tillage and sowing took place about a week before the normal time.

Soil samples for porosity measurements were taken with metal cylinders of height $4.9 \mathrm{~cm}$, inside diameter $7.2 \mathrm{~cm}$, and volume $200 \mathrm{~m}^{3}$. The samples were collected during the two weeks following the later sowing time, when the moisture content of soil deeper than $10 \mathrm{~cm}$ was still near the field capacity, or a few percentage points lower by volume. An exception was the

Table 1. Characteristics of experimental soils. Top soil $=a$, subsoil $=b$.

\begin{tabular}{|c|c|c|c|c|c|c|}
\hline \multirow[t]{2}{*}{ Field } & & \multicolumn{4}{|c|}{ Particle size distribution } & \multirow{2}{*}{$\begin{array}{c}\text { Org. C } \\
\% \text { of D.M. }\end{array}$} \\
\hline & & 200 & $20-200$ & $2-20$ & $2 \mu \mathrm{m}$ & \\
\hline \multirow[t]{2}{*}{ Espoo 1} & a & 4 & 13 & 31 & 52 & 3.2 \\
\hline & $\mathrm{b}$ & 0 & 9 & 25 & 66 & 0.7 \\
\hline \multirow[t]{2}{*}{ Espoo 2} & $\mathbf{a}$ & 4 & 16 & 43 & 37 & 2.9 \\
\hline & b & 2 & 15 & 35 & 48 & 1.1 \\
\hline \multirow[t]{2}{*}{ Mietoinen 1} & a & 3 & 9 & 23 & 65 & 2.2 \\
\hline & b & 1 & 4 & 19 & 76 & 0.9 \\
\hline \multirow[t]{2}{*}{ Mietoinen 2} & $\mathbf{a}$ & 5 & 26 & 22 & 47 & 1.9 \\
\hline & b & 1 & 7 & 24 & 68 & 0.7 \\
\hline \multirow[t]{2}{*}{ Anjala } & $\mathbf{a}$ & 4 & 13 & 28 & 55 & 2.6 \\
\hline & b & 2 & 12 & 18 & 68 & 0.9 \\
\hline \multirow[t]{2}{*}{ Laukaa } & $\mathbf{a}$ & 0 & 13 & 62 & 25 & 1.8 \\
\hline & b & 0 & 13 & 63 & 24 & 0.3 \\
\hline
\end{tabular}


Laukaa field where the soil tended to dry quickly after sowing. The samples were taken as follows:

1976. Mietoinen 1: on CO-, C2 and C3-plots, from successive layers of $5 \mathrm{~cm}$ from the surface to the depth of $40 \mathrm{~cm}$. Other fields: on CO-, C1-, C2- and C3-plots, only from the layer of 10-15 cm.

1977. Espoo 1: on CO-, C2- and C3-plots, from successive layers of $5 \mathrm{~cm}$ to the depth of $40 \mathrm{~cm}$. Other fields: on C0-, C1-, C2- and C3-plots, from the layer of 10-15 cm.

1978. Espoo 1 and Mietoinen 1: on $\mathrm{CO}$ - and C3-plots, from the surface to $40 \mathrm{~cm}$. Other fields: on $\mathrm{CO}$-, C1-, C2- and C3-plots, from the layer of 10-15 cm.

The number of replications in the field trials was 4 . There was a special sampling area at both ends of the plots. The number of replications in sampling was at least 8 . Samples were moistened in the laboratory by placing the cylinders on a fine sand bed, where the water potential had a value of -5 $\mathrm{cm}$. Thereafter the cylinders were transferred onto ceramic plates and the water potential regulated to $-100 \mathrm{~cm}$. When equilibrium was attained, the weights of the moist soils were recorded and the soils were dried in an oven. Soil density was determined by the pyknometer method (BLAKE 1965). The proportions of solid substance, water and air space in soil were then calculated. In 1978 some profiles in Espoo 1 from a soil sown with seed earlier than usual were studied more closely. Then porosity conditions were determined by equilibrating the samples of these profiles to the potentials of $-2.5,-5,-10,-50$ and $-100 \mathrm{~cm}$. The pore diameter corresponding to the water potential was calculated using the formula (e.g. CZERATZKI 1958):

$$
d=\frac{0.3}{h}
$$

where $\mathrm{d}=$ pore diameter in $\mathrm{cm}$

$\mathrm{h}=$ absolute value of capillary potential of soil water expressed as height of water column in $\mathrm{cm}$

\section{Results}

a. Effect of soil compaction on the porosity conditions

The results for the profile samples are shown in Figures 1, 2 and 5. The average water contents just before spring tillage at the depth of $5-20 \mathrm{~cm}$ in ploughed fields are presented in Table 2. Table 2 also presents the water contents at the water potential of -0.1 bars corresponding to the moisture content at the field capacity.

The profile samples taken in 1976 from Mietoinen 1 indicate that the traffic most severely compacted the soil below the harrowed layer of the soil, at the depth of $10-15 \mathrm{~cm}$. The proportion of large pores by volume was particularly reduced. The soil was compacted most severely when the harrowing and drilling were performed under wet conditions about one week before the usual time. The large pore space in the layer from 0 to $10 \mathrm{~cm}$ is due to spring tillage. The effect of compaction on porosity was weak in subsoil: at the depth of $35-40 \mathrm{~cm}$ there was no clear difference in the pore space between 

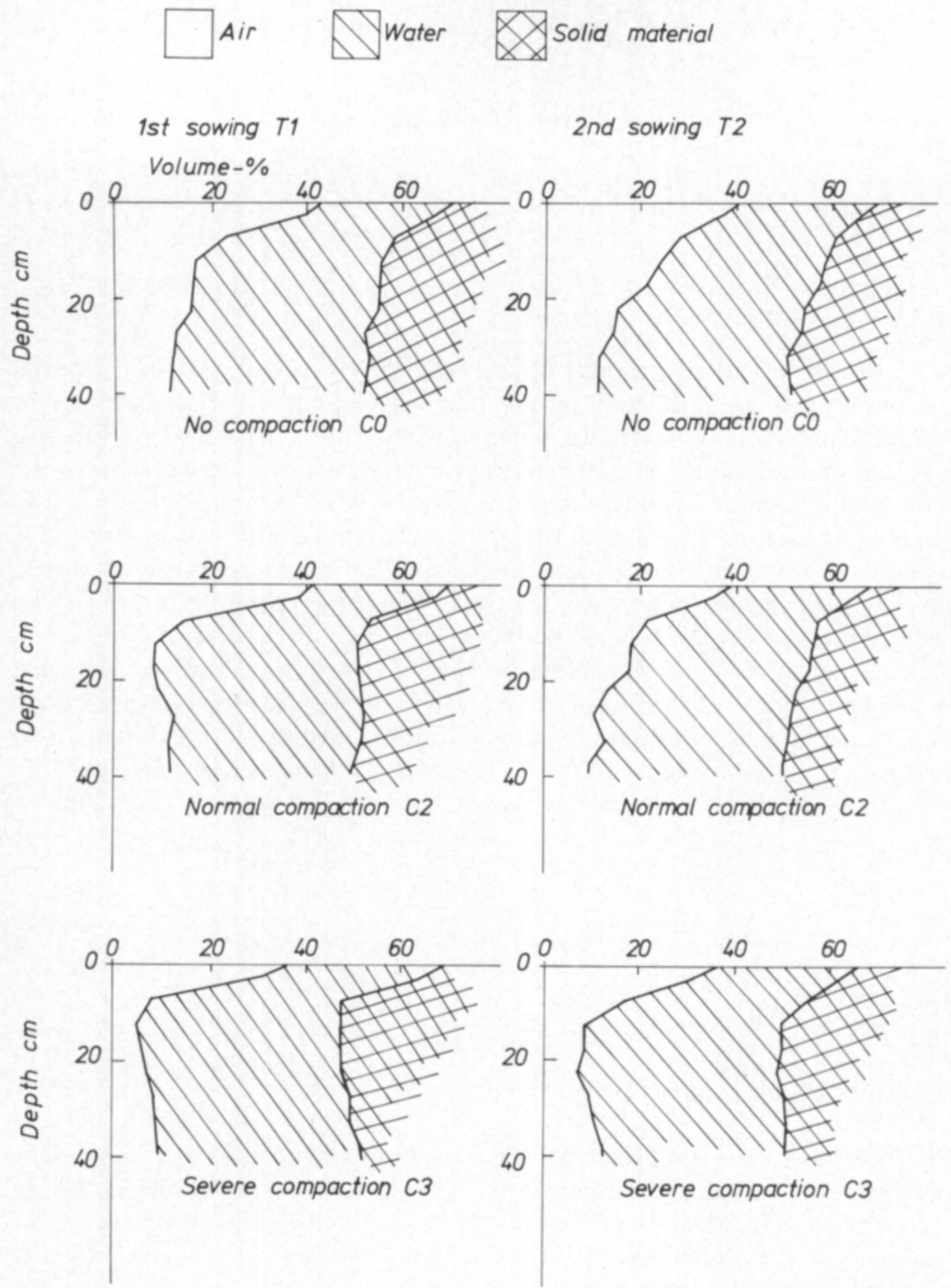

Fig. 1. Porosity conditions at the depth of $0-40 \mathrm{~cm}$ in the field of Mietoinen 1 in 1976. The moisture content corresponds to water potential of -0.1 bars.

the treatments. The profile samples of 1977 from Espoo 1 confirm the above results, as do the results of Mietoinen 1 in 1978 (Figure 5). The profiles of Espoo 1 in 1978 show, however, that severe compaction under wet conditions in the spring can strongly reduce the volume of large pores in subsoil, too. According to Figures 1,2 and 5 the minimum volume of large pores after 


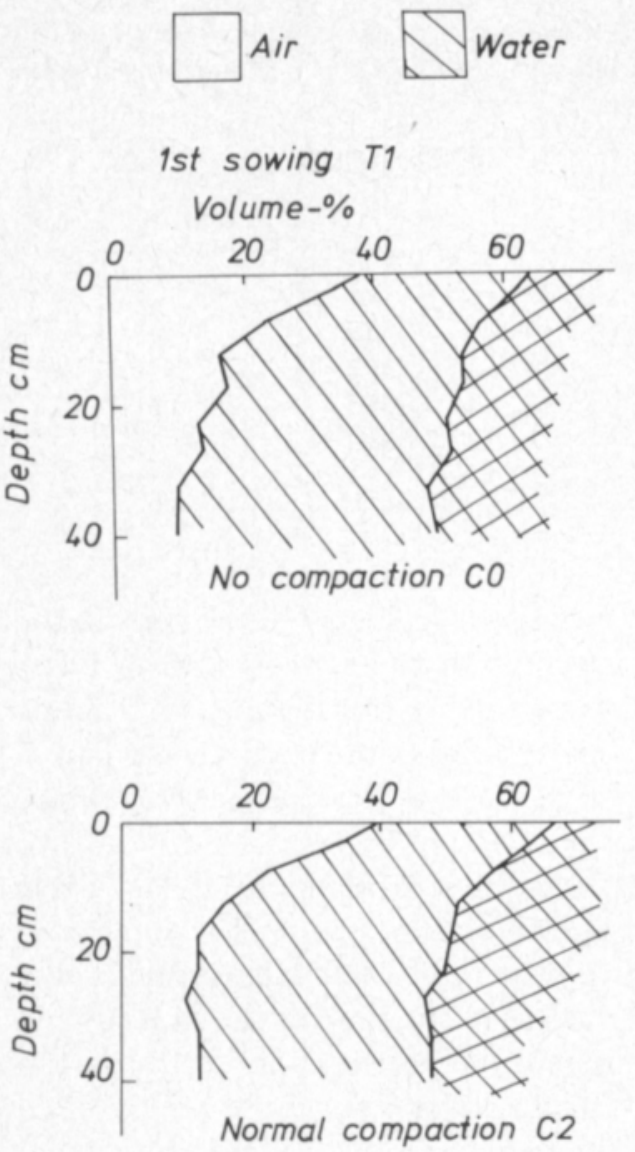

XSolid material

2nd sowing $T 2$
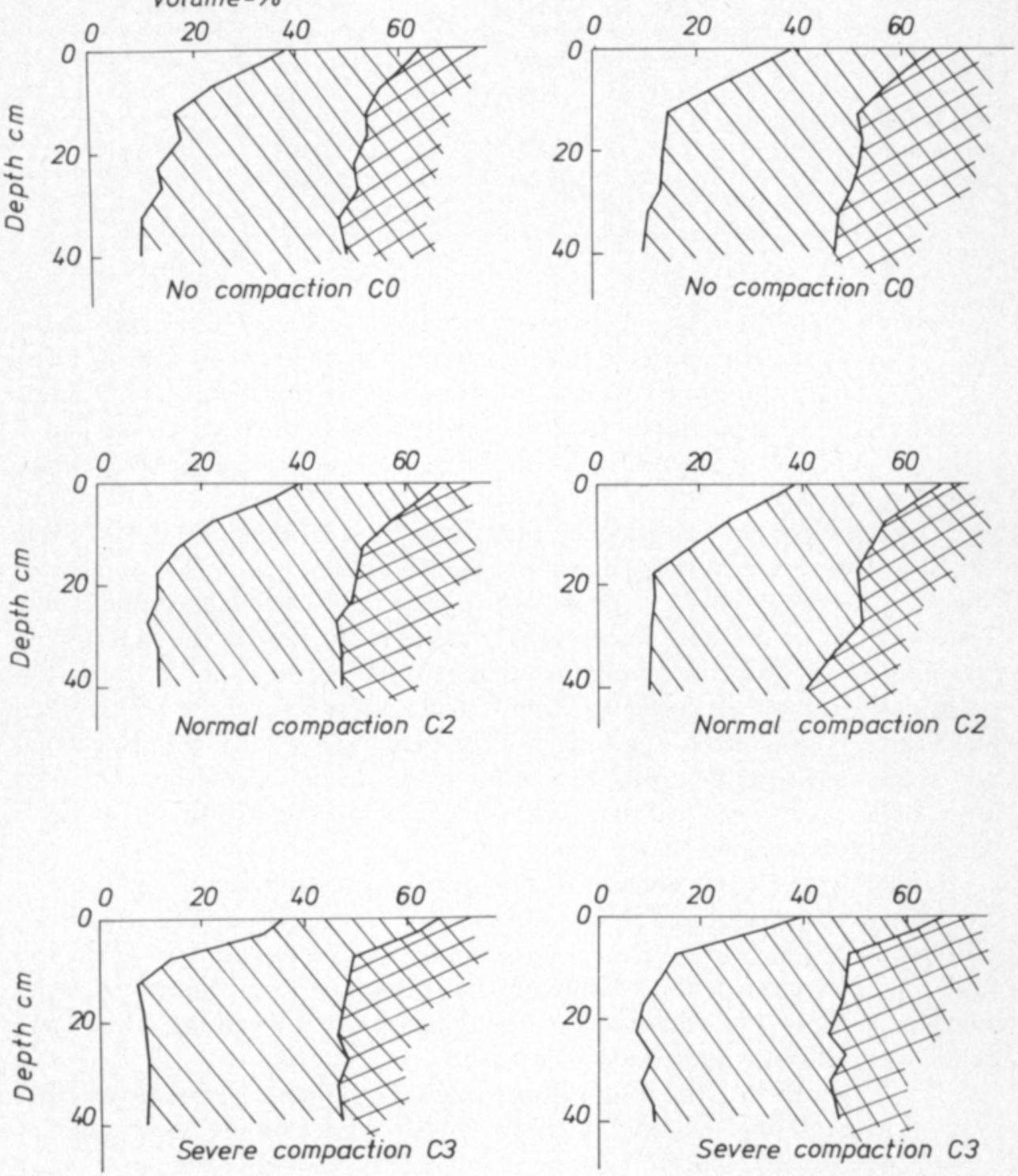

Fig. 2. Porosity conditions at the depth of $0-40 \mathrm{~cm}$ in the field of Espoo 1 in 1977. The moisture content corresponds to water potential of -0.1 bars.

strong compaction is found at the depth of $10-25 \mathrm{~cm}$ but there is also a decrease at the deeper layers.

Table 3 confirms the results in Figures 1, 2 and 5. Compaction reduced the total space and especially the volume of the large pores in the layer of $10-15 \mathrm{~cm}$. The changes in soil structure were greater during spring tillage in 
Table 2. The average water contents at the depth of $5-20 \mathrm{~cm}$ just before spring tillage. Volume- $\%$. Early sowing $=\mathrm{T} 1$, normal sowing $=\mathrm{T} 2$. Measurements by ELONEN $(1979)$. The water contents at -0.1 bars in $\mathrm{C} 0$-plots are also shown.

\begin{tabular}{lcccccc}
\hline & \multicolumn{2}{c}{${ }^{1976}$} & \multicolumn{2}{c}{1977} & 1978 & $\begin{array}{c}\text { Water content at the } \\
\text { potential of }-0.1 \text { bars }\end{array}$ \\
& T1 & T2 & T1 & T2 & T1 & \\
\hline Espoo 1 & 38.1 & 30.2 & 44.1 & 38.2 & 41.5 & 36 \\
Espoo 2 & 34.9 & 28.9 & 39.9 & 38.3 & 35.5 & 37 \\
Mietoinen 1 & 38.3 & - & 36.7 & 37.6 & 41.2 & 38 \\
Mietoinen 2 & 34.8 & - & 30.0 & 29.2 & 33.5 & 32 \\
Anjala & 38.9 & 35.5 & 38.2 & 39.3 & 38.4 & 35 \\
Laukaa & 37.5 & 28.7 & 38.7 & 35.7 & 36.5 & 39 \\
\hline
\end{tabular}

wet conditions than tillage at the normal time. In spring 1977 the soils in the Mietoinen 1 and Anjala fields did not become drier between sowing times (Table 2) but, rather, rainy wheather caused further moistening. As Table 3 shows, in 1977 compacting of the soil in these fields at the normal time had as harmful an effect on the volume of the large pores as the traffic at the earlier sowing time.

The results of the Laukaa field differ from those of the other fields (Table $3)$. Even the strongest compacting of the soil did not reduce the total pore space or the volume of large pores. Nor did the time of sowing influence the results of this field. Table 2 shows that the soil at the time of the first sowing was already drier than the moisture content at the potential of -0.1 bars. On account of its high silt content (Table 1), the Laukaa field could not be tilled until the soil moisture content reached the field capacity. Table 3 shows that the percentage of large pores by volume in the Laukaa field was not much over $10 \%$ even in the soil that had not been compacted. In the other fields the corresponding percentage was about $20 \%$.

Evidently the water content of soil was not the only factor determining the effect of compaction (Tables 2 and 3 and Figure 3). Especially in Espoo 1 and Espoo 2 there was no clear correlation between water content of the soil and degree of compaction. Although the soil was drier at the two sowing times in 1976 than in other springs, the reduction in the volume of the large pores by traffic was greatest in that year.

Table 3 shows that the compaction of the soil was about the same whether tractors were double-wheeled or single-wheeled. On average, the volume of large pores in the C1-plots was one percentage point higher than in the C2plots, when tillage was done a week before the normal time.

\section{b. Porosity and yield}

Yield results showed that in most cases only severe compaction (C3) caused a significant lowering of grain yield (ELONEN 1979). There was no great difference in the porosity between the $\mathrm{C} 1$ - and $\mathrm{C} 2$-treatments and therefore no great difference in yield between these treatments. In the T1- 
Table 3. Porosity conditions at the depth of $10-15 \mathrm{~cm}$. Early sowing $=\mathrm{T} 1$, normal sowing time $=\mathrm{T} 2$.

Year

Volume-\%

Small and medium

\begin{tabular}{|c|c|c|}
\hline Solid material & Sized pores & Large pores \\
\hline $\begin{array}{llll}\mathrm{CO} & \mathrm{C} 1 & \mathrm{C} 2 & \mathrm{C} 3\end{array}$ & $\mathrm{Cl}^{2}$ & \\
\hline
\end{tabular}

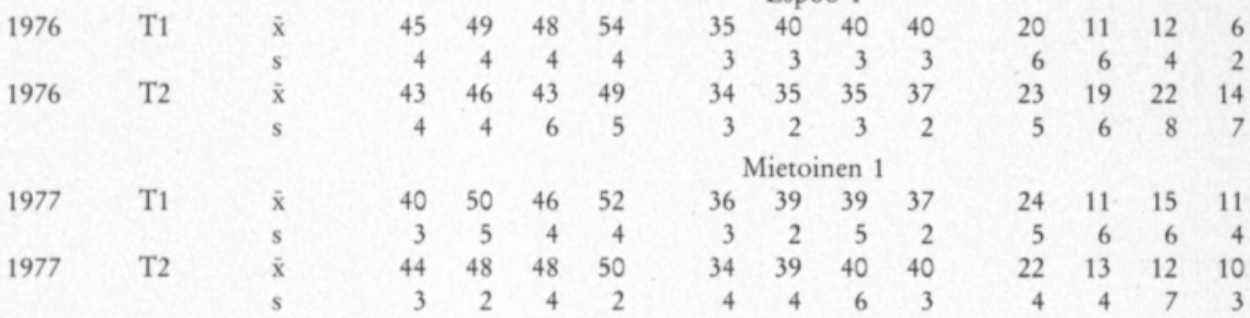

Espoo 1

\section{Espoo 2}

$\begin{array}{rllrrrrrrrrrrrr}1976 & \text { T1 } & \bar{x} & 47 & 48 & 50 & 53 & 39 & 40 & 42 & 42 & 14 & 12 & 8 & 5 \\ & & s & 4 & 3 & 2 & 2 & 2 & 3 & 1 & 1 & 5 & 4 & 2 & 2 \\ 1976 & \text { T2 } & \bar{x} & 42 & 43 & 45 & 47 & 38 & 37 & 37 & 39 & 20 & 20 & 18 & 14 \\ & & s & 4 & 3 & 3 & 5 & 3 & 2 & 3 & 2 & 7 & 4 & 5 & 5 \\ 1977 & \text { T1 } & \bar{x} & 43 & 47 & 52 & 53 & 35 & 35 & 35 & 38 & 22 & 18 & 13 & 9 \\ & & s & 2 & 4 & 3 & 3 & 2 & 2 & 2 & 2 & 4 & 5 & 4 & 2 \\ 1977 & \text { T2 } & \bar{x} & 43 & 45 & 46 & 50 & 37 & 38 & 36 & 36 & 20 & 17 & 18 & 14 \\ & & s & 4 & 2 & 5 & 6 & 4 & 4 & 3 & 6 & 7 & 4 & 7 & 6 \\ 1978 & \text { T1 } & \tilde{x} & 46 & 48 & 49 & 52 & 34 & 35 & 35 & 34 & 20 & 17 & 16 & 14 \\ & & & s & 5 & 4 & 4 & 3 & 3 & 3 & 3 & 4 & 8 & 4 & 6\end{array}$

\section{Mietoinen 2}

\begin{tabular}{|c|c|c|c|c|c|c|c|c|c|c|c|c|c|c|}
\hline \multirow[t]{2}{*}{1976} & $\mathrm{~T} 1$ & $\tilde{\mathbf{x}}$ & 48 & 53 & 55 & 58 & 34 & 36 & 38 & 37 & 18 & 11 & 7 & 5 \\
\hline & & $s$ & 4 & 2 & 3 & 4 & 5 & 3 & 2 & 3 & 8 & 3 & 2 & 2 \\
\hline \multirow{2}{*}{1976} & T2 & $\overline{\mathbf{x}}$ & 45 & 47 & 48 & 49 & 32 & 34 & 33 & 35 & 23 & 19 & 19 & 16 \\
\hline & & $s$ & 4 & 4 & 3 & 3 & 2 & 2 & 2 & 2 & 5 & 3 & 2 & 3 \\
\hline \multirow[t]{2}{*}{1977} & $\mathrm{~T} 1$ & $\overline{\mathbf{x}}$ & 46 & 50 & 51 & 56 & 32 & 33 & 34 & 32 & 22 & 17 & 15 & 12 \\
\hline & & $s$ & 3 & 5 & 4 & 6 & 3 & 3 & 3 & 3 & 5 & 7 & 5 & 5 \\
\hline \multirow[t]{2}{*}{1977} & T2 & $\overline{\mathbf{x}}$ & 43 & 46 & 46 & 50 & 30 & 32 & 34 & 34 & 27 & 22 & 20 & 16 \\
\hline & & $s$ & 3 & 4 & 4 & 4 & 2 & 3 & 3 & 4 & 4 & 7 & 4 & 5 \\
\hline \multirow[t]{3}{*}{1978} & $\mathrm{~T} 1$ & $\overline{\mathbf{x}}$ & 49 & 50 & 51 & 53 & 31 & 32 & 33 & 34 & 20 & 18 & 16 & 13 \\
\hline & & $s$ & 5 & 2 & 3 & 4 & 3 & 3 & 5 & 4 & 7 & 4 & 4 & 7 \\
\hline & & & & & & & & $\mathrm{An}$ & & & & & & \\
\hline \multirow[t]{2}{*}{1976} & $\mathrm{~T} 1$ & $\overline{\mathbf{x}}$ & 42 & 46 & 44 & 52 & 35 & 39 & 37 & 40 & 23 & 15 & 19 & 8 \\
\hline & & $s$ & 5 & 3 & 4 & 4 & 4 & 5 & 3 & 3 & 7 & 7 & 5 & 4 \\
\hline \multirow[t]{2}{*}{1976} & T2 & $\overline{\mathbf{x}}$ & 43 & 45 & 42 & 50 & 35 & 36 & 36 & 40 & 22 & 19 & 22 & 10 \\
\hline & & $s$ & 2 & 4 & 5 & 4 & 3 & 5 & 3 & 3 & 4 & 6 & 7 & 3 \\
\hline \multirow[t]{2}{*}{1977} & T1 & $\tilde{\mathbf{x}}$ & 45 & 49 & 48 & 52 & 35 & 38 & 39 & 39 & 20 & 13 & 13 & 9 \\
\hline & & s & 6 & 4 & 3 & 4 & 4 & 3 & 5 & 5 & 9 & 5 & 6 & 3 \\
\hline \multirow[t]{2}{*}{1977} & T2 & $\overline{\mathbf{x}}$ & 45 & 49 & 47 & 51 & 37 & 37 & 39 & 39 & 18 & 14 & 14 & 10 \\
\hline & & $s$ & 4 & 5 & 5 & 5 & 4 & 4 & 3 & 4 & 7 & 7 & 6 & 8 \\
\hline \multirow[t]{3}{*}{1978} & T1 & $\overline{\mathbf{x}}$ & 48 & 50 & 50 & 54 & 33 & 34 & 35 & 37 & 19 & 16 & 15 & 9 \\
\hline & & $s$ & 4 & 5 & 5 & 5 & 3 & 4 & 3 & 4 & 5 & 7 & 7 & 6 \\
\hline & & & & & & & & Lat & & & & & & \\
\hline \multirow[t]{2}{*}{1976} & $\mathrm{~T} 1$ & $\tilde{\mathbf{x}}$ & 49 & 48 & 51 & 52 & 40 & 41 & 39 & 40 & 11 & 11 & 10 & 8 \\
\hline & & s & 3 & 4 & 5 & 3 & 2 & 2 & 3 & 2 & 4 & 4 & 6 & 3 \\
\hline \multirow[t]{2}{*}{1976} & T2 & $\overline{\mathbf{x}}$ & 47 & 49 & 48 & 47 & 41 & 40 & 40 & 40 & 12 & 11 & 12 & 13 \\
\hline & & $s$ & 4 & 2 & 4 & 3 & 3 & 2 & 2 & 1 & 5 & 4 & 5 & 4 \\
\hline \multirow[t]{2}{*}{1977} & T1 & $\overline{\mathbf{x}}$ & 51 & 50 & 49 & 51 & 38 & 40 & 37 & 37 & 11 & 10 & 14 & 12 \\
\hline & & s & 3 & 3 & 5 & 5 & 2 & 3 & 3 & 2 & 2 & 4 & 7 & 6 \\
\hline \multirow[t]{2}{*}{1977} & $\mathrm{~T} 2$ & $\overline{\mathbf{x}}$ & 50 & 51 & 49 & 49 & 40 & 39 & 36 & 38 & 10 & 10 & 15 & 13 \\
\hline & & $s$ & 4 & 3 & 4 & 5 & 2 & 2 & 8 & 1 & 3 & 3 & 9 & 6 \\
\hline \multirow[t]{2}{*}{1978} & T1 & $\overline{\mathbf{x}}$ & 49 & 50 & 49 & 52 & 38 & 37 & 38 & 36 & 13 & 13 & 13 & 12 \\
\hline & & $s$ & 5 & 2 & 3 & 5 & 3 & 3 & 2 & 2 & 6 & 3 & 4 & 5 \\
\hline
\end{tabular}


Large pores $(\phi>0.03 \mathrm{~mm})$

in the layer of $10-15 \mathrm{~cm}$

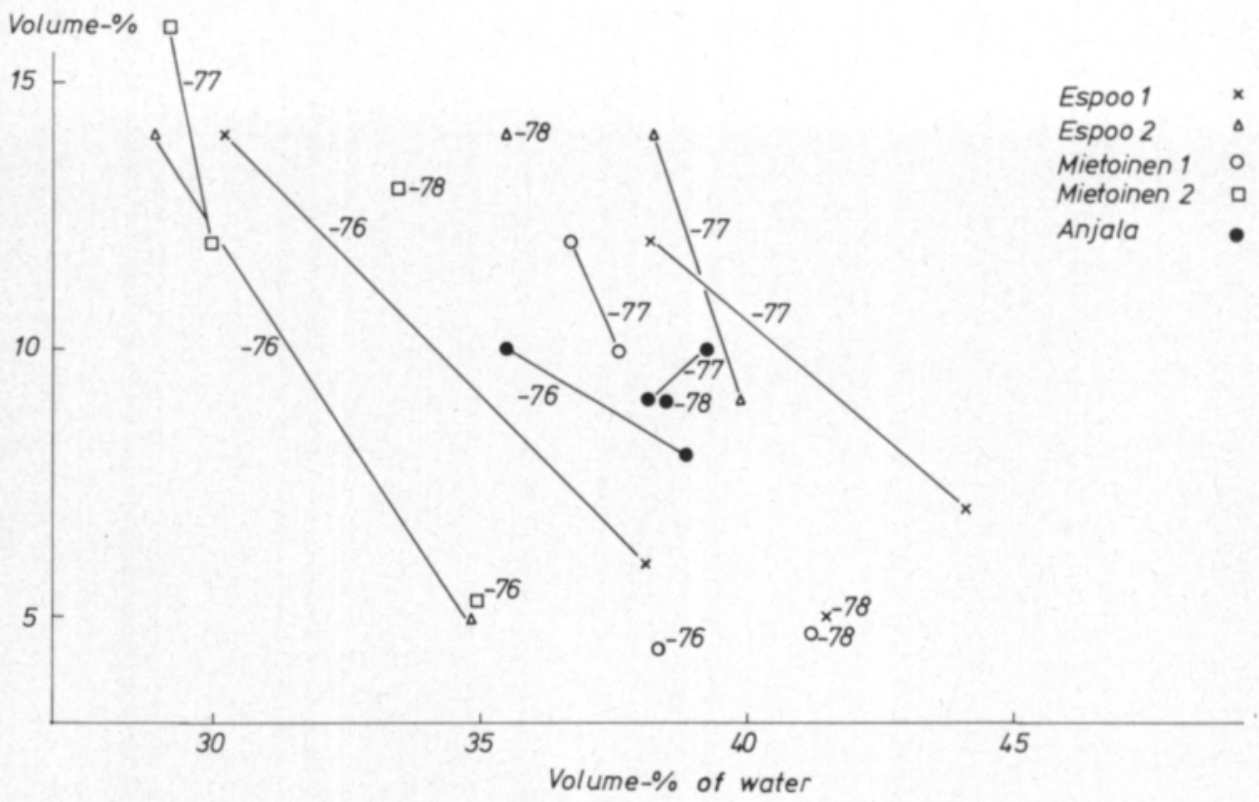

Fig. 3. Water content of soil at sowing time and the volume of large pores in C3-plots.

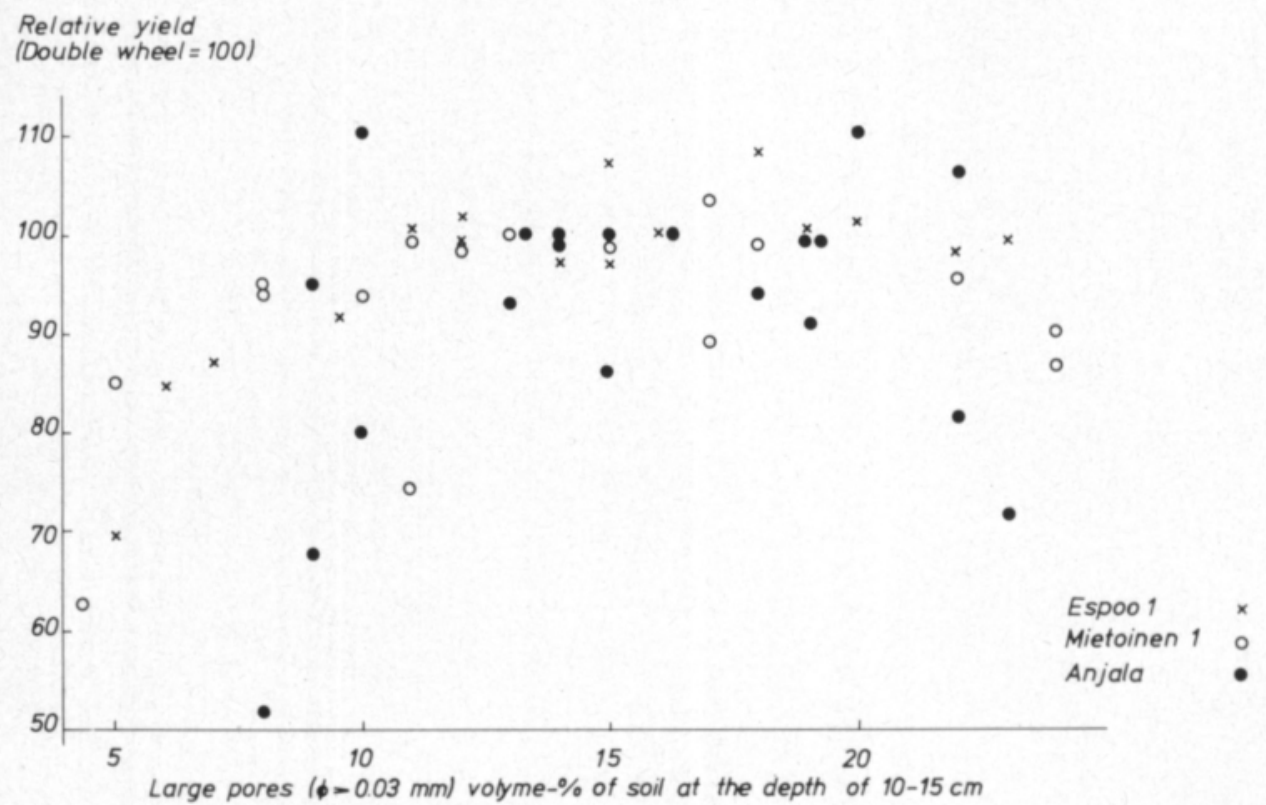

Fig. 4. Large pores and yields. 
plots, driving with a single-wheeled tractor compacted soil on average slightly more than driving with a double-wheeled tractor. Accordingly, the C1T1-treatment gave a $100-\mathrm{kg}$ higher yield than the C2T1-treatment. The porosity measurements of the Laukaa field accorded with the yields of that field: traffic on the field affected neither the porosity nor the yield level.

In the heaviest clay soils, Espoo 1, Mietoinen 1 and Anjala, the moisture content below the harrowed layer remained near the field capacity until the crop sprouts began strong transpiration, whereas the lighter soils lost much of the water content before the emergence of the sprouts. Apparently the measured porosities of Espoo 1, Mietoinen 1 and Anjala described the conditions in the soil for a longer period during the early summer than did the results from the other fields. Figure 4 shows how the yields of the former fields depended on the volumes of the large pores. The relative yield of the $\mathrm{C} 1$-treatment is indicated by 100 . Figure 4 also shows that traffic will strongly decrease grain yield when large pores in the layer at $10-15 \mathrm{~cm}$ are decreased to about $10 \%$ by volume or less.

c. Improvement in the strucrute of compacted soil

In 1978 all Tl-plots were harrowed and drilled using double-wheeled vehicles at the normal planting time. The after-effect of severe compaction (C3) in comparison with the treatment without compaction (CO) is shown in Figure 5. In soil of Espoo 1 the after-effect was slight and in Mietoinen 1 no after-effect was observable. Table 4 confirms these results: the soils had almost completely recovered from severe compaction by following year, 1978. The yield results were in accordance with porosity measurements and there were no significant differences between the aftereffect plots (ELONEN 1979).

Table 4. The after-effect of soil compaction on porosity conditions a year after the soil was compacted. The samples are taken from the layer at $10-15 \mathrm{~cm}$. The time of sowing was normal.

\begin{tabular}{|c|c|c|c|c|c|c|c|c|c|c|c|c|c|}
\hline \multirow[t]{2}{*}{ Field } & & \multicolumn{4}{|c|}{ Solid material } & \multicolumn{4}{|c|}{$\begin{array}{l}\text { Volume-\% } \\
\text { Small and medium } \\
\text { Sized pores }\end{array}$} & \multicolumn{4}{|c|}{ Large pores } \\
\hline & & $\mathrm{CO}$ & $\mathrm{C} 1$ & $\mathrm{C} 2$ & $\mathrm{C} 3$ & $\mathrm{CO}$ & $\mathrm{C} 1$ & $\mathrm{C} 2$ & $\mathrm{C} 3$ & $\mathrm{CO}$ & $\mathrm{C} 1$ & $\mathrm{C} 2$ & $\overline{\mathrm{C} 3}$ \\
\hline Espoo 2 & $\begin{array}{l}\overline{\mathrm{x}} \\
\mathrm{s}\end{array}$ & $\begin{array}{r}50 \\
4\end{array}$ & $\begin{array}{r}49 \\
6\end{array}$ & $\begin{array}{r}51 \\
4\end{array}$ & $\begin{array}{r}50 \\
5\end{array}$ & $\begin{array}{r}35 \\
3\end{array}$ & $\begin{array}{r}35 \\
2\end{array}$ & $\begin{array}{r}35 \\
4\end{array}$ & $\begin{array}{r}34 \\
4\end{array}$ & $\begin{array}{r}15 \\
6\end{array}$ & $\begin{array}{r}16 \\
6\end{array}$ & $\begin{array}{r}14 \\
7\end{array}$ & $\begin{array}{r}16 \\
8\end{array}$ \\
\hline Mietoinen 2 & $\begin{array}{l}\overline{\mathbf{x}} \\
S\end{array}$ & $\begin{array}{r}52 \\
4\end{array}$ & $\begin{array}{r}53 \\
3\end{array}$ & $\begin{array}{r}50 \\
3\end{array}$ & $\begin{array}{r}51 \\
3\end{array}$ & $\begin{array}{r}31 \\
3\end{array}$ & $\begin{array}{r}32 \\
2\end{array}$ & $\begin{array}{r}33 \\
3\end{array}$ & $\begin{array}{r}32 \\
3\end{array}$ & $\begin{array}{r}17 \\
5\end{array}$ & $\begin{array}{r}15 \\
2\end{array}$ & $\begin{array}{r}17 \\
6\end{array}$ & $\begin{array}{r}17 \\
3\end{array}$ \\
\hline Anjala & $\begin{array}{l}\tilde{\mathrm{x}} \\
\mathrm{s}\end{array}$ & $\begin{array}{r}51 \\
6\end{array}$ & $\begin{array}{r}49 \\
6\end{array}$ & $\begin{array}{r}50 \\
5\end{array}$ & $\begin{array}{r}49 \\
5\end{array}$ & $\begin{array}{r}35 \\
3\end{array}$ & $\begin{array}{r}32 \\
5\end{array}$ & $\begin{array}{r}34 \\
3\end{array}$ & $\begin{array}{r}36 \\
4\end{array}$ & $\begin{array}{r}14 \\
8\end{array}$ & $\begin{array}{r}19 \\
6\end{array}$ & $\begin{array}{r}16 \\
6\end{array}$ & $\begin{array}{r}15 \\
6\end{array}$ \\
\hline Laukaa & $\begin{array}{l}\overline{\mathrm{x}} \\
\mathrm{s}\end{array}$ & $\begin{array}{r}51 \\
2\end{array}$ & $\begin{array}{r}50 \\
4\end{array}$ & $\begin{array}{r}51 \\
4\end{array}$ & $\begin{array}{r}48 \\
3\end{array}$ & $\begin{array}{r}37 \\
3\end{array}$ & $\begin{array}{r}37 \\
3\end{array}$ & $\begin{array}{r}37 \\
2\end{array}$ & $\begin{array}{r}36 \\
3\end{array}$ & $\begin{array}{r}12 \\
4\end{array}$ & $\begin{array}{r}13 \\
5\end{array}$ & $\begin{array}{r}12 \\
5\end{array}$ & $\begin{array}{r}16 \\
5\end{array}$ \\
\hline
\end{tabular}



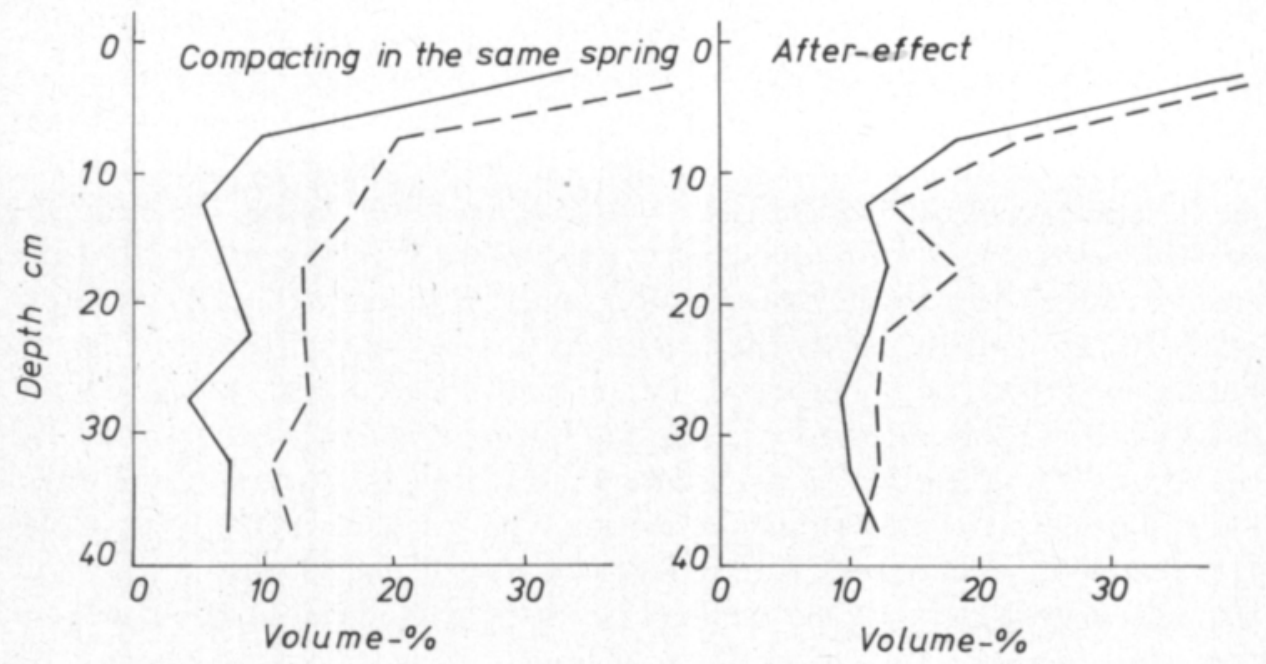

Mietoinen 11978
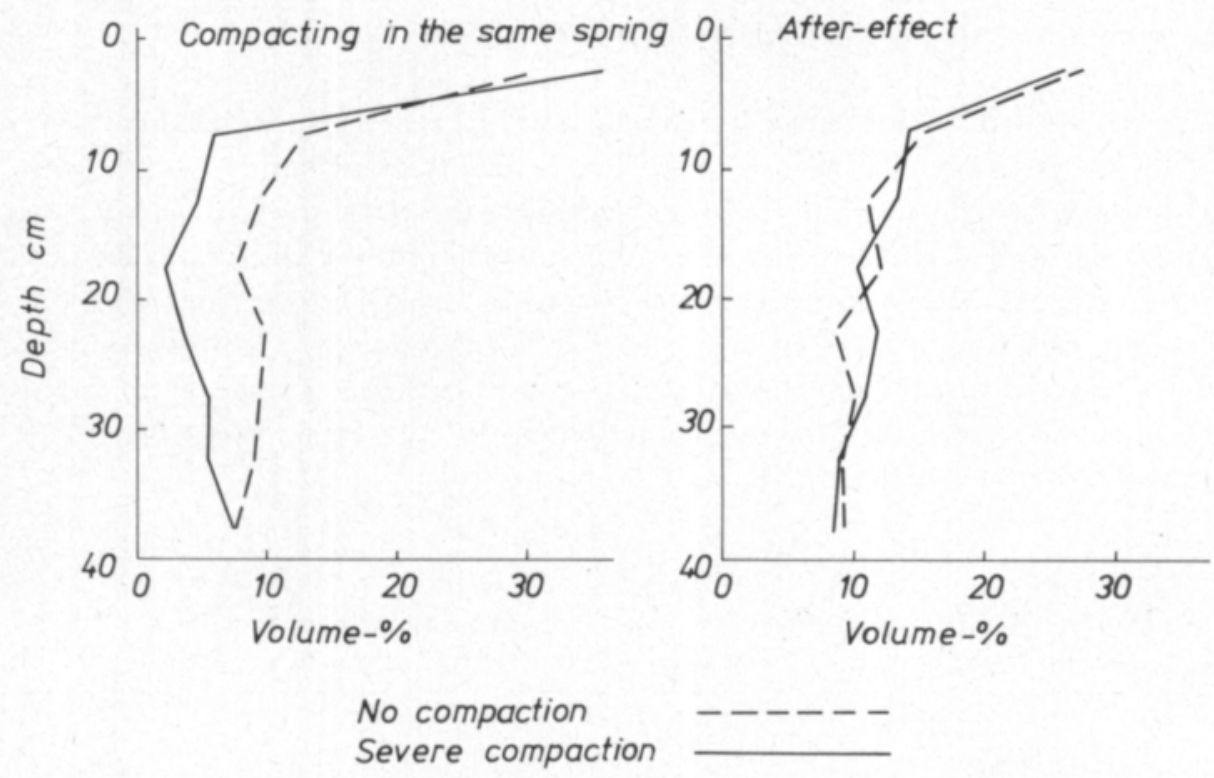

Fig. 5. Large pores in the fields Espoo 1 and Mietoinen 1 in 1978.

d. Reduction of volume and density of large pores by soil compaction

The effect of soil compaction on the proportions of large pores of various sizes is presented in Figure 6. A detailed analysis of large pores was performed on some $\mathrm{CO}$ - and $\mathrm{C} 3$-profiles from Espoo 1. Figure 6 shows a sharp rise in the volume of air-filled pores when the interval of the water potential lies between 0 and $-2.5 \mathrm{~cm}$. These largest pores are apparently the air spaces in the cracks crossing the soil sample in various directions. This 


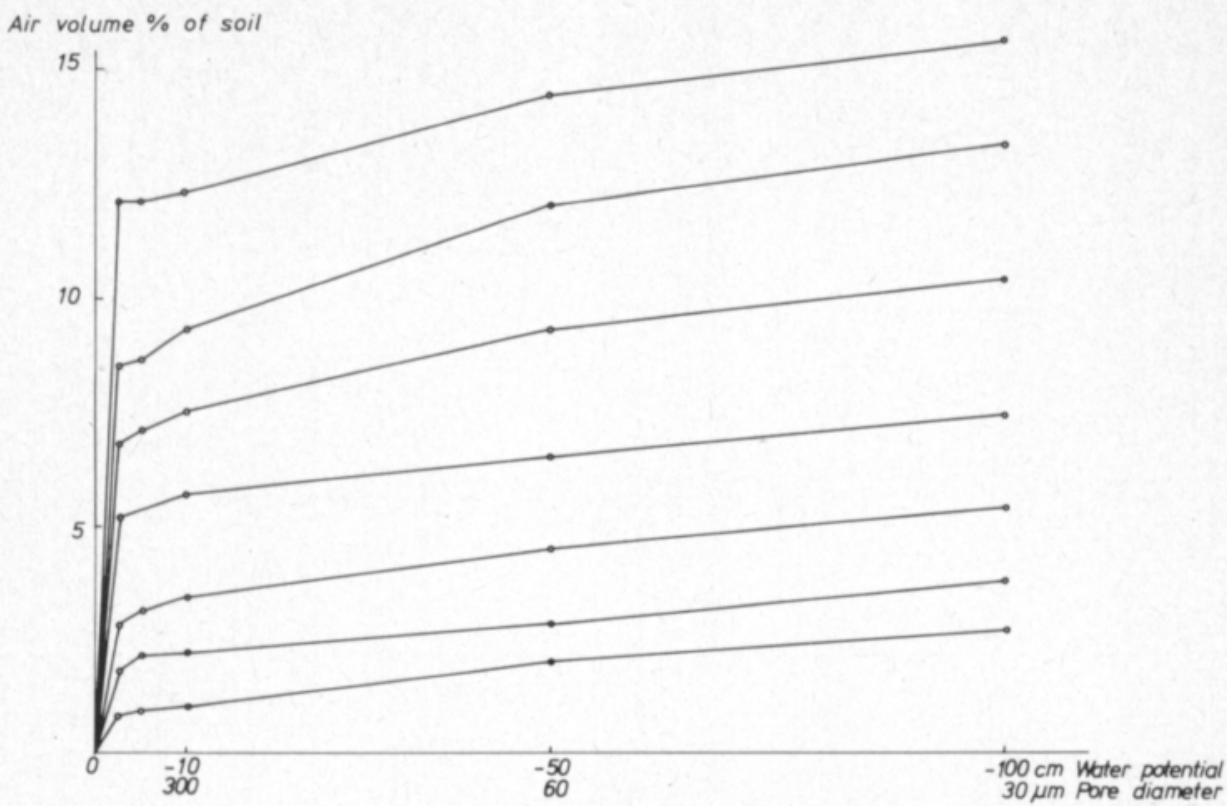

Fig. 6. Effect of compaction on the volume of air in the soil. The water potential is from 0 to $-100 \mathrm{~cm}$.

space was strongly decreased by soil compaction. The increase for the interal between -2.5 and $-100 \mathrm{~cm}$ was not so sharp. However, it should be noted that differences in porosity are not due only to tractor traffic but also to the natural compaction of soil before the spring tillage.

An approximate value of the pore density was calculated from the graphs presented in Figure 6 as follows (Figure 7): If the absolute value of the soil water potential $\mathrm{h}$ increases by the amount of $\mathrm{dh}$, this correspondingly raises the volume of airfilled pores by $d v\left(\mathrm{~cm}^{3} / \mathrm{cm}^{3}\right)$. Between the points $h_{1}$ and $h_{2}$ the air volume varies nearly linearly with the value of h, or:

$$
\begin{aligned}
& \mathrm{v}=\frac{\mathrm{v}_{2}-\mathrm{v}_{1}}{\mathrm{~h}_{2}-\mathrm{h}_{1}} \mathrm{~h}+\text { constant } \\
& \mathrm{dv}=\mathrm{kdh}
\end{aligned}
$$

The length of the pores $\mathrm{dl}$ corresponding to the increase of the air volume can be derived by dividing $d v$ by $\pi(D / 2)^{2}$, where $\mathrm{D}$ is the diameter of pores:

$$
\mathrm{dl}=\mathrm{k} \frac{\mathrm{dh}}{\pi(\mathrm{D} / 2)^{2}}
$$

By equation (1):

$$
\begin{aligned}
& \mathrm{dl}=\mathrm{k} \frac{\mathrm{dh}}{\pi(0.3 / 2 \mathrm{~h})^{2}}=14.15 \mathrm{kh}^{2} \mathrm{dh} \\
& \mathrm{L}_{2}=\int_{\mathrm{h}_{1}}^{\mathrm{h}_{2}} \mathrm{dl}=4.72 \mathrm{k}\left(\mathrm{h}_{2}^{3}-\mathrm{h}_{1}^{3}\right) \mathrm{cm} / \mathrm{cm}^{3} \\
& \mathrm{~L}=\mathrm{L}_{1}+\mathrm{L}_{2}+\mathrm{L}_{3}+\ldots
\end{aligned}
$$


Air volume $\mathrm{cm}^{3} / \mathrm{cm}^{3}$

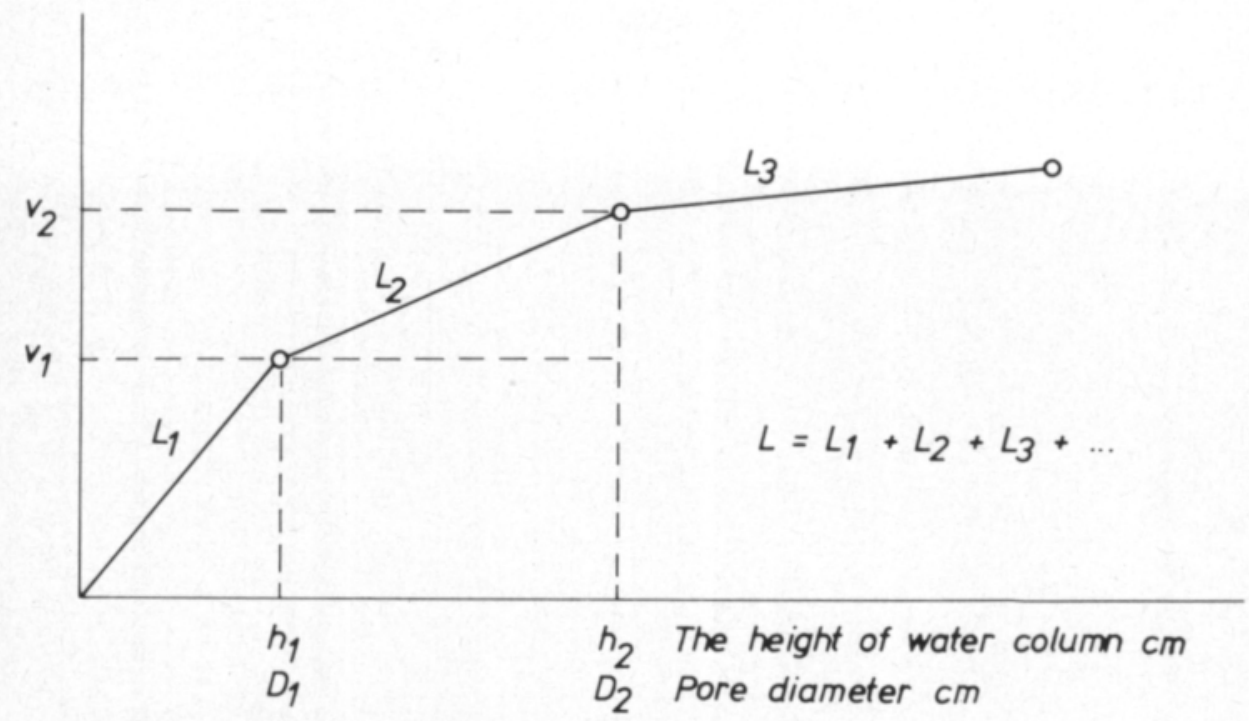

Fig. 7. Calculation of pore density using the water retention curve.

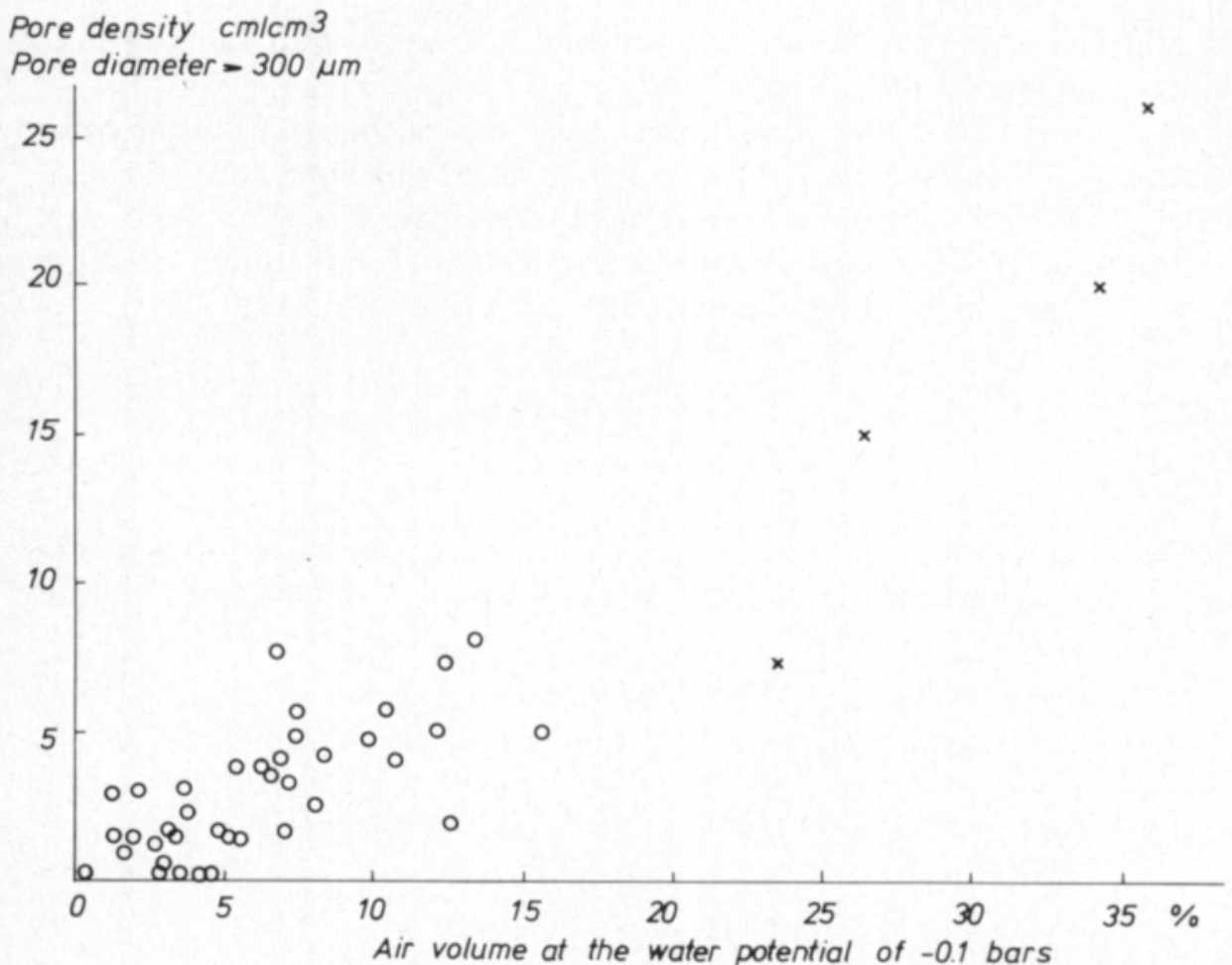

Fig. 8. Dependence of pore density on compaction. Pore diameter $>300 \mu \mathrm{m} . \mathrm{x}=$ the harrowed layer $0-5 \mathrm{~cm}$. 
Pore density $\mathrm{cm}^{\mathrm{cm}} \mathrm{cm}^{3}$

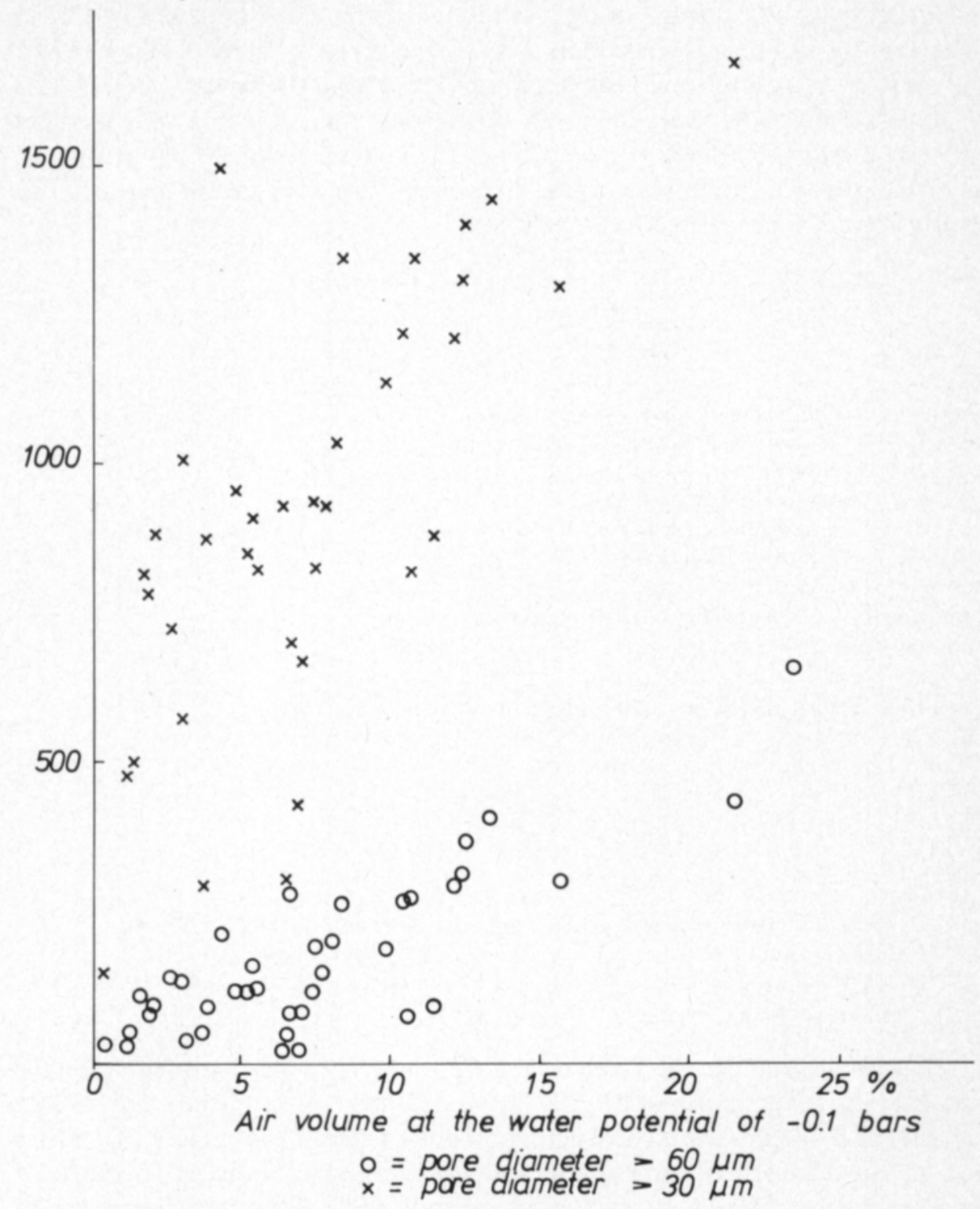

Fig. 9. Dependence of pore density on compaction.

The pore densities calculated according to equation (6) are presented in Figures 8 and 9 . Figure 8 shows that in compacted soil the density of pores $>$ $300 \mu \mathrm{m}$ in diameter may be near zero. The density of pores larger than $60 \mu \mathrm{m}$ or larger than $30 \mu \mathrm{m}$ is also dependent on soil compaction.

e. Calculation of oxygen adequacy in compacted soil

An approximate idea of the effect of the compacting of soil on aeration can be estimated in the following way: As the profile samples showed, the 
harrowed layer has a great air volume and the diffusion of gases is hindered only slightly if the surface of the soil is not encrusted. The harrowed layer dries rapidly and the respiration in this layer is approximately 0 . Assume that the owygen consumption at the depth of $5-25 \mathrm{~cm}$ is $10 \mathrm{l} / \mathrm{m}^{2}$ day (MONTEITH et al. 1964, BROWN et al. 1965). In the subsoil the use of oxygen is slight (RICHTER and GROSSGEBAUER 1978). If the concentration of oxygen in the air space of soil changes slowly, the streaming of oxygen in soil is nearly in a steady state. Hence (van BAVEL 1951):

$$
\begin{aligned}
& q=-D \frac{d C}{d z} \\
& \frac{d^{2} C}{d z^{2}}=\frac{a}{D}
\end{aligned}
$$

where $\mathrm{q}=$ the diffusion of oxygen downward $\mathrm{mg} / \mathrm{cm}^{2} \mathrm{~s}$

$\mathrm{C}=$ the concentration of oxygen in soil air $\mathrm{mg} / \mathrm{cm}^{3}$

$\mathrm{z}=$ the depth $\mathrm{cm}$

$\mathrm{a}=$ the use of oxygen by soil $\mathrm{mg} / \mathrm{cm}^{3} \mathrm{~s}$

$\mathrm{D}=$ the macro-diffusion coefficient of oxygen in soil $\mathrm{cm}^{2} / \mathrm{s}$

$101 \mathrm{O}_{2} / \mathrm{m}^{2}$ day in the layer of $5-25 \mathrm{~cm}=7.7 \times 10^{-7} \mathrm{mg} / \mathrm{cm}^{3} \mathrm{~s}$

Boundary conditions are:

$5 \mathrm{~cm}: \mathrm{C}=\mathrm{C}_{0}=0.2095 \mathrm{~cm}^{3} / \mathrm{cm}^{3}=0.2786 \mathrm{mg} / \mathrm{cm}^{3}$

$25 \mathrm{~cm}: \mathrm{dC} / \mathrm{dz}=0(\mathrm{q}=0)$

Thus equation (8) has the solution (van BAVEL 1951):

$$
\begin{aligned}
& C=0.5 \frac{a}{D} z^{2}-\frac{a}{D} L z+C 0 \\
& L=20 \mathrm{~cm} \\
& D=D_{0} \varepsilon k
\end{aligned}
$$

where $D_{0}=$ the diffusion coefficient of oxygen in air $0.21 \mathrm{~cm}^{2} / \mathrm{s}$ (LAX 1967, WEAST 1969)

$\varepsilon=$ the proportion of air space in soil; the value 0.05 is used in calculation

$k=$ the coefficient representing the continuity of pores; the value 0.3 is used in this calculation (see e.g, RICHTER and GRLSSBEBAUER 1978)

By substituting the values of a, D, L, $\mathrm{C}_{0}$ and $\mathrm{z}(=20 \mathrm{~cm})$ into equation (9) we obtain $\mathrm{C}$ at the depth of $25 \mathrm{~cm}$. The computed concentration of $\mathrm{O}_{2}$ is 0.23 $\mathrm{mg} / \mathrm{cm}^{3}$ or $0.17 \mathrm{~cm}^{3} / \mathrm{cm}^{3}$. The calculation shows that if the surface of a soil is not encrusted normal compaction probably does not cause a shortage of oxygen at least in the inter-crumb pores of the soil during the growing season, when the soil most of the time is drier than at the field capacity.

\section{Discussion}

As mentioned above, the fields Espoo 2, Mietoinen 2 and Laukaa tended to dry rapidly after the second drilling (T2) if precipitation was poor. The cracking of soil soon followed, which should help the roots to grow downward, but on the other hand soil shrinkage between cracks makes the soil harder for the roots to penetrate than the pore measurements showed. 
The heaviest clay soils Espoo 1, Mietoinen 1 and Anjala dried more slowly and began to loose moisture rapidly only when sprouts started vigorous transpiraton. At this time the heaviest clay soils cracked and the porosity between the cracks was lower than that obtained by the porosity measurements. However, the porosity measurements described the conditions in these fields at an early stage of the growth cycle which was apparently important for the development of the crop.

The compacting of the soil by spring traffic primarily reduced the volume of the large pores in soil. Thus the hydraulic conductivity for saturated soil was reduced in the compacted soil. The streaming velocity of water in a thin tube is proportional to the square of the radius of the tube. Hence small changes in the volume of large pores mean great changes in conductivity, as RASMUSSEN (1976) has shown for example. In hard rains water may remain on the soil surface because the infiltration rate is reduced by soil compaction. Consequently, compaction causes a dispersion of soil surface structure and thus reduces soil aeration and crop growth.

The aeration of soil depends on the rapidity of the diffusion of gases. Contrary to hydraulic conductivity, the diffusion coefficient of oxygen is determined by the total air porosity of soil. The calculation presented in this paper suggests that compaction by normal traffic does not cause a shortage of oxygen in the inter-crumb pores of soil if the soil surface structure is not. dispersed and encrusted.

The reduction of growth on compacted field seems to be primarily due to mechanical impedance to crop roots. If the pore walls are not at all elastic the roots cannot penetrate pores smaller in diameter than the extending zone of the roots (WIERSUM 1957). Even a slight hinderance can greatly restrict root elongation. RUSSELL and GOSS (1974) have shown that a pressure of 0.2 bars against the roots of barley can reduce root extension to about half that of the control. Because the diameter of the laterals of the root system of crops is about $300 \mu \mathrm{m}$ (WIERSUM 1957, FINNEY and KNIGHT 1973), the density of pores greater in diameter than $300 \mu \mathrm{m}$ greatly influences the development of crop roots. In the harrowed surface layers the maximum density of crop roots can be about $10-20 \mathrm{~cm} / \mathrm{cm}^{3}$, but in the deeper layers the density is less than $5 \mathrm{~cm} / \mathrm{cm}^{3}$ (BARLEY 1970, WELBANK et al. 1974). These values are comparable to the porosity densities of pores $>300 \mu \mathrm{m}$ in diameter. The pore densities were calculated from the desorption section of the water retention curve. In this way the large pores, that were blocked and had a poor continuity, were not taken into consideration in the calculations.

A significant finding of this study was that the severely compacted soil had nearly recovered by the following spring. The factors responsible could be the deep frost in Finland (KIVISAARI 1979) and the successive wetting and drying of soil. In winter 1977-78 the maximum depths reached by frost in the vicinity of the experimental fields were as follows: Espoo $64 \mathrm{~cm}$, Mietoinen $94 \mathrm{~cm}$, Laukaa $21 \mathrm{~cm}$ and Anjala $57 \mathrm{~cm}$.

According to the yield results soil compaction clearly decreases yield when the volume of large pores in the layer of $10-15 \mathrm{~cm}$ is reduced to about $10 \%$ or less. On the basis of field experiments CZERATZKI (1966) has 

will suffer and the yield be reduced.

Acknowledgements. The author wishes to thank those people who carried out the compacting experiments in the field and to express his gratitude to Professor P. Elonen, Professor O. Kara and to the directors of experimental stations: J. Köylijärvi, P. Simojoki and K. Virri.

\section{References}

BARLEY, K. P. 1970. The configuration of the root system in relation to nutrient uptake. Adv. Agron. 22: 159-201.

van BAVEL, C. H. M. 1951. A soil aeration theory based on diffusion. Soil Sci. 72: 33-46.

BLAKE, G. R. 1965. Particle density. Agronomy 9: 371-373.

BROWN, N. J., FOUNTAINE, E. R. \& HOLDEN, M. R. 1965. The owygen requirement of crop roots and soils under near field conditions. J. Agric. Sci. 64: 195-203.

CZERATZKI, W. 1958. Eine keramische Platte zur serienmässigen Untersuchung von Porengrössen im Boden im Spannungsbereich bis ca -1 Atm. Z. Pfl.ernähr. Düng. Bodenkunde 81: 50-56.

- 1966. Die Charakterisierung von bearbeitungsbeeinflussten Bodeneigenschaften in Beziehung zum Pflanzenwachstum. Landbauforsch. Völkenrode 16: 37-44.

ELONEN, P. 1979. Maan tiivistymisen vaikutus kevätviljasatoihin. Maataloustutkimuksen Päivät B1-B6. 2. 1979. Moniste 21 p. Helsinki.

ELONEN, P. 1980. Soil compaction - a severe problem in Finnish agriculture. Rapp. fråm jordbearbetningsavdelningen, $\mathrm{Nr} .60 .5$ p. Uppsala.

ERIKSSON, J., HÅKANSSON, I. \& DANFORS, B. 1974. Jordpackning-markstruktur-gröda. Inverkan av maskiner och fordon. Jordbrukstekniska institutet. Medd. 354: 1-78.

FINNEY, J. R. \& KNIGHT, B. A. G. 1973. The effect of soil physical conditions produced by various cultivation systems on the root development of winter wheat. J. Agric. Sci. Camb. 80: 435-442.

KIVISAARI, S. 1979. Effect of moisture and freezing on some physical properties of clay soils from plough layer. J. Scient. Agric. Soc. Finl. 51: 245-326.

LAX, E. 1967. Taschenbuch für Chemiker und Physiker. Band I. 1522 p. Berlin.

MONTEITH, J. L. 1964. Crop photosynthesis and the flux of carbon dioxide below the canopy. J. Appl. Ecol. 1: 321-337.

RASMUSSEN: K. J. 1976. Danish experiments on soil compaction. Lantbrukshögskolan Uppsala. Institutionen för markvetenskap. Rapporter från Jordbearbetningsavdelningen 45, 32: 1-4 .

RICHTER, J. \& GROSSGEBAUER, A. 1978. Untersuchungen zum Bodenlufthaushalt in einem Bodebearbeitungsversuch. 2. Gasdiffusionskoefficienten als Strukturmasse für Böden. Z. Pfl.ernähr. Bodenkunde 141: 181-202.

RUSSELL, R. S. \& GOSS, M. J. 1974. Physical aspects of soil fertility. - The response of roots to mechanical impedence. Neth. J. Agric. Sci. 22: 305-318.

WEAST, R. C. 1969. Handbook of chemistry and physics. 2356 p. Cleveland.

WELBANK, P. J., GIBB, M. J., TAYLOR, P. J. \& WILLIAMS, E. D. 1973. Root growth of cereal crops. Rothamsted Experimental Station. Report 1973. Part 2: 26-66.

WIERSUM, L. K. 1957. The relationship of the size and structural rigidity of pores to their penetration by roots. Plant and Soil 9: 75-85.

Ms received January 18, 1983 


\title{
Traktorilla ajon vaikutus kevätmuokkaus- ja kylvötöiden aikana maan huokoisuuteen
}

\author{
Erkki Aura \\ Maatalouden tutkimuskeskus, maanviljelyskemian ja -fysiikan osasto, 31600 Jokioinen.
}

Maasta otettujen sylinterinäytteiden avulla tutkittiin keväällä kylvötöiden yhteydessä tapahtuvan tiivistämisen vaikutusta maan huokoisuuteen. Profiilinäytteet osoittivat, että traktorilla ajo tiivistää eniten äestyskerroksen alapuolella $10-25 \mathrm{~cm}: n$ syvyydessä olevaa maakerrosta. Tämä kerros tiivistyy erityisesti silloin, kun muokkaus- ja kylvötyöt suoritetaan normaalia aikaisemmin. Pohjamaa tiivistyy ainoastaan, jos maa muokkausaikana on erittäin märkää. Huokoisuusmittausten mukaan käytettäessä traktorissa paripyöriä maa tiivistyy suunnilleen yhtä paljon kuin käytettäessä tavallisia pyöriä, jos kylvö suoritetaan normaaliin aikaan. Aloitettaessa kevätmuokkaus normaalia aikaisemmin voi paripyörien käyttö estää tiivistymistä.

Tulosten analysointi osoitti, että maan kosteus kylvöhetkellä ei ollut ainoa tekijä, joka vaikutti tiivistämisen tehokkuuteen. Maan huokoisuus kylvön jälkeen rïppui kosteuden ja traktorilla ajon lisäksi myös muista maan rakenteeseen vaikuttavista tekijöistä. Tulosten mukaan selviä sadonalennuksia saadaan vasta, kun suurten huokosten tilavuus maassa 10-15 $\mathrm{cm}: \mathrm{n}$ kerroksessa on tiivistämisen johdosta alentunut noin $10 \%$ :iin tai tämän arvon alapuolelle. Näin pieneen huokoisuuteen pästään yleensä vain normaalia aikaisemmin suoritetulla rankalla tiivistämisellä. Huokoisuusmittausten mukaan savimaan rakenne toipuu lähes täysin edellisenä keväänä aiheutetuista vakavista tiivistysvaurioista.

Teoreettiset laskelmat osoittivat, että mikäli maan pinta ei ole liettynyt ja irtovesi valuu riittävän nopeasti ojastoon, ei kasvin juuristo normaalin traktorilla ajon johdosta kärsi hapen puutetta ainakaan maan suurimmissa huokosissa. Tïvistäminen heikentää kasvua lähinnä sen vuoksi, että kohonnut mekaaninen vastus maassa rajoittaa juuriston kehitystä. 